\title{
当院における重症筋無力症の予後についての検討 一高齢発症重症筋無力症および眼筋型重症筋無力症を中心に一
}

\author{
近藤 正樹 ${ }^{1)}$ 滋賀 健介 ${ }^{1)}$ 水野 敏樹1) 伊地智俊晴2) 中川 正法 ${ }^{1)}$
}

\begin{abstract}
〈要 約〉（目的）高齢発症および眼筋型重症筋無力症（MG）患者の治療，予後について検討する.（方 法）当科入院患者データベースから $\mathrm{MG}$ 患者を抽出し検討した。 1991 年 4 月から 2003 年 12 月の間に $\mathrm{MG}$ が 58 例あり, 発症年齢によって高齢群 (65 歳以上), 非高齢群 (20 歳から 64 歳), 若年群 (19 歳以下) に, また病型によって眼筋型と全身型に分類して治療と予後を検討した（結果）高齢群と非高齢群の検討：高 齢群は 11 例であった。高齢群の内訳は眼筋型 4 例, 全身型 7 例であった。高齢群では非高齢群と同様に女 性の比率が高かった．抗アセチルコリンレセプター抗体結合型（以下抗 AchR 抗体と略す）は 11 例全例で 陽性であり, 平均 $27.2 \mathrm{nmol} / l$ であった. 4 例で胸腺病変を認めた. 当院で治療された 10 例のうち 6 例でス テロイド薬が使用され，4例で胸腺摘除術が施行されていた４例が抗コリンエステラーゼ薬（抗 ChE 薬） のみで治療されていた。一方，4例で再燃を認め，このうち 2 例でクリーゼがみられた．眼筋型の検討： 眼筋型は 21 例であった. 抗 AchR 抗体は 12 例で陽性であり，異常高值を示した 1 例を除くと平均 $22.2 \mathrm{nmol} / l$ であった．治療法は 12 例でステロイド薬が使用され，4 例で胸腺摘除術が施行されていた。抗 $\mathrm{ChE}$ 薬のみの治療例は 8 例であった。経過観察期間中に全身型へ移行したと判断された症例は 1 例であっ た. 症状改善例は 16 例でこのうち著明改善例は 6 例であった（結論）今回の検討では高齢群ではステロ イド薬の導入・減量は, ステロイド薬の副作用,他の合併症に関連して慎重な対応が必要であり,予後にも重 要な影響があると考えられた．眼筋型の検討では，全身型への移行例が 1 例のみで，多数例で症状の改善 を認めた．多くの症例でステロイド治療が行われていたことが，良好な予後に寄与していた可能性が示唆 された.
\end{abstract}

Key words：重症笳無力症，高齢発症，眼筋型，治療，予後

（日老医誌 $2005 ； 42 ： 546$ 一552）

\section{緒言}

重症筋無力症（MG）に対して近年ステロイド療法を はじめとする種々の治療法が試みられており，一定の成 果がみられている。しかしながら，高齢発症 $M G に$ 関 しては非高齢発症 $M G$ と病態が幾分異なる可能性があ ること，加齢に伴う身体機能の低下や合併症がみられる ことから, 非高齢発症 $M G$ とは治療, 予後が異なるも のと推定される．同様のことは，全身型 $\mathrm{MG}$ に対する 眼筋型 MGについても考えられ，治療方針は未だ充分 に確立されていない1). 今回我々は，高齢発症および眼 筋型 MGに焦点をおいて当院における治療と予後の検 討を行った.

\section{方法}

当院神経内科入院患者データベースから $M G$ 患者を

1) M. Kondo, K. Shiga, T. Mizuno, M. Nakagawa：京都 府立医科大学 神経内科・老年内科

2) T. Ijichi：済生会滋賀県病院 神経内科

受付日：2004.11.22，採用日：2005. 3.22
抽出し，診療録から情報を収集し，後ろ向き研究として 検討を行った. $\mathrm{MG}$ の診断の判定は臨床症状, エドロホ ニウム静注試験で行い, 神経反復刺激検査（以下 RSST と略す）の低頻度刺激での減衰現象を参考とした．胸腺 病変は胸部 CT で判定し, 胸腺摘除術を施行した症例は 病理所見を記載した。症例は発症年齢によって高齢群 $(65$ 歳以上), 非高齢群 (20 歳から 64 歳), 若年群 (19 歳以 下)に分類し，成人発症の高齢群と非高齢群を比較した. また病型によって全身型と眼筋型を比較した．眼筋型の 診断は臨床症状が眼症状に限定され，エドロホニウム静 注試験陽性，RSST で四肢・体幹筋に減衰現象を認めな かった症例とした．治療前後で診療録の記載を参考にし て ADL スコア $(\text { 表 } 1)^{2)}$ で重症度を評価した。な掠，ADL スコアが 1 以上変動した場合を改善 (ないし増悪)とし, ADL スコアが 0 になった場合を著明改善とした。退院 後に当院外来に通院していなかった症例については，転 院先の病院に連絡し全身型への移行の有無を問い合わせ た. 
表 1 ADL スコア（免疫性神経疾患調査研究班平成 7 年度研究報告より改変）

0. 症状なし

1. 軽微な症状のみにて日常生活, 勤務, 通学に支障なし. (軽度の眼症状).

2. 中等度の症状のため勤務，学校生活などが十分遂行できない（重度の眼症状).

3. 症状が強く, 勤務, 学校, 外出などがほとんど出来ない.

構音・曣下障害もみられることがある。

4. 室内の移動, 身の回りのことがかろうじて可能, 構音・鷬下障害も強いことが多い,

5. 寝たきり，もしくは椅子に座ったまま，歩行不能.

6. 常時, もしくは時々, 人工呼吸器装着.

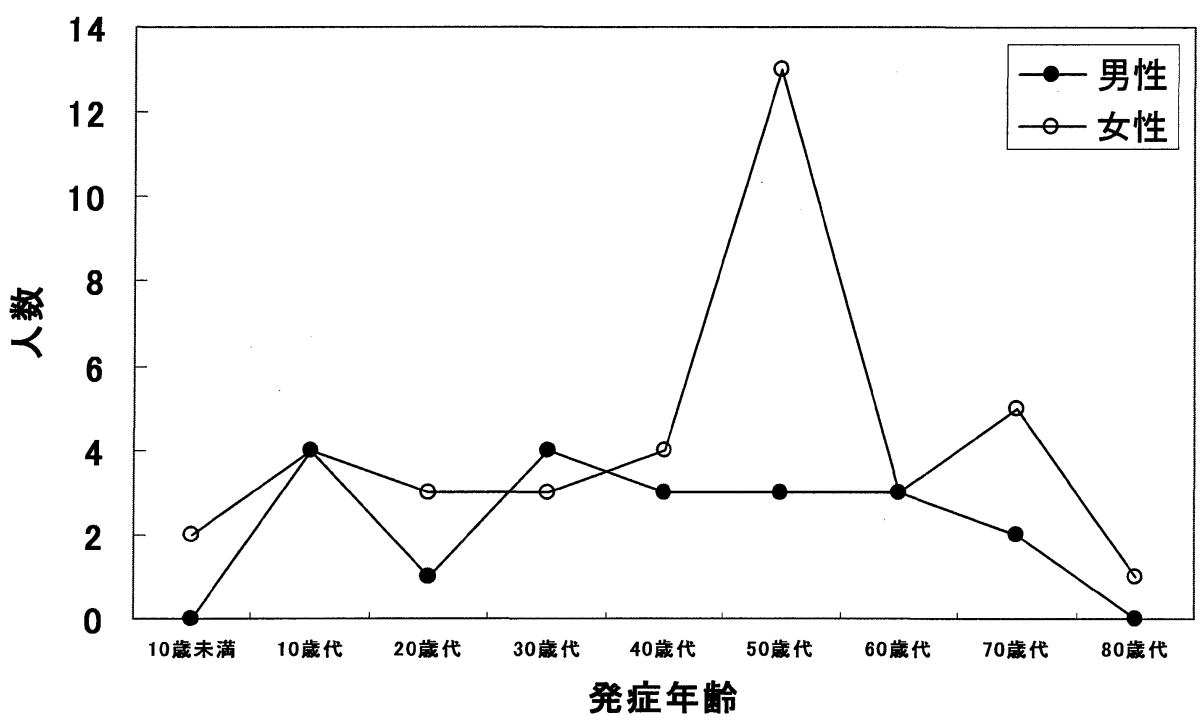

図 1 男女の年齢分布

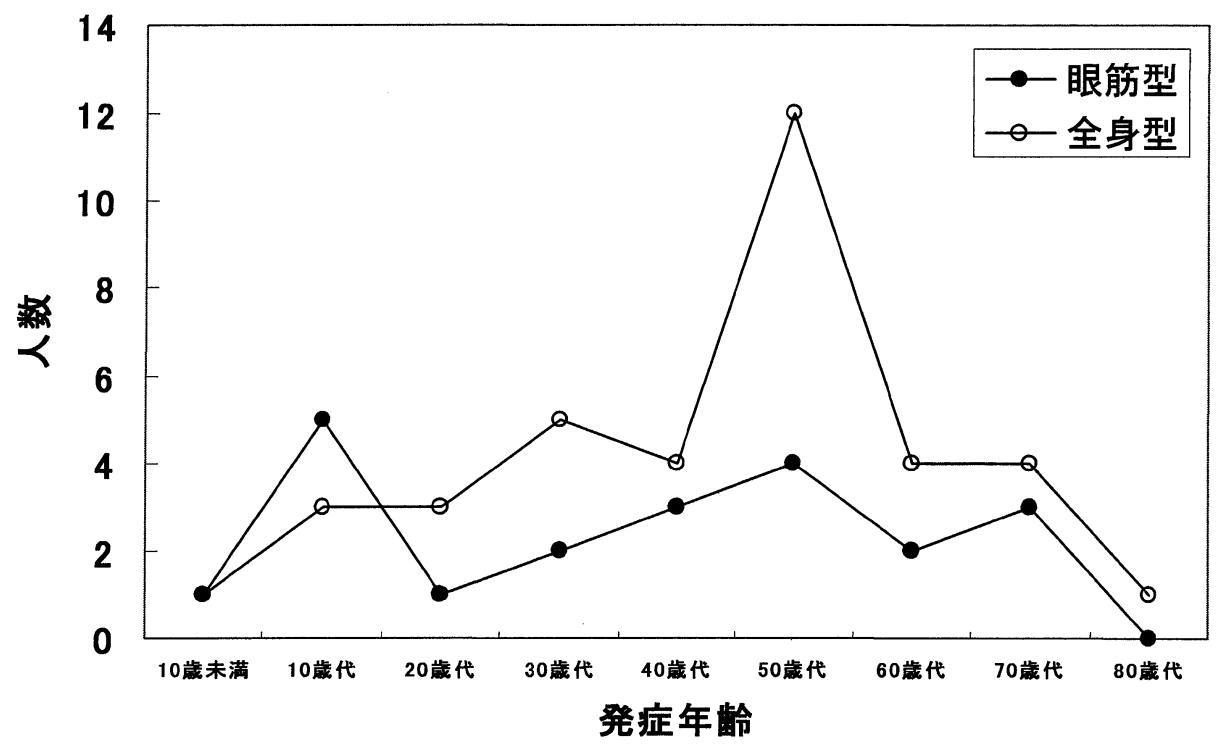

図 2 眼筋型および全身型の年齢分布 


\begin{tabular}{|c|c|c|}
\hline 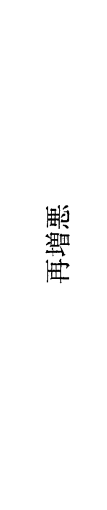 & 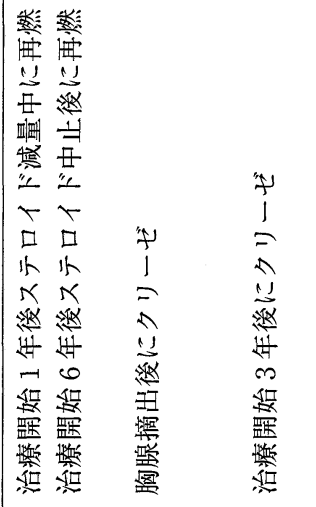 & \\
\hline$\underset{\sim}{\frac{N}{2}}$ & $00-1-r-N$ & 100 \\
\hline 壮人 & 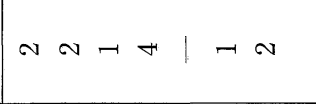 & 000 \\
\hline 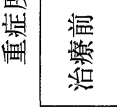 & $m \infty \sim N \sim N$ & $\neg \neg \infty$ \\
\hline 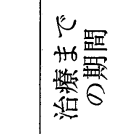 & 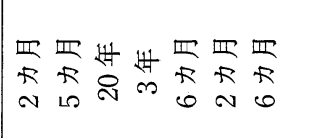 & 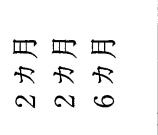 \\
\hline 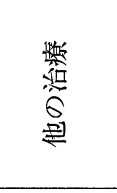 & 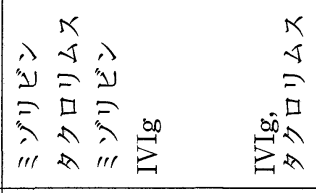 & ì \\
\hline 㖄 & 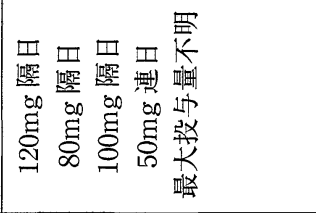 & \\
\hline 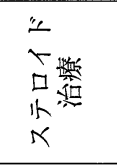 & 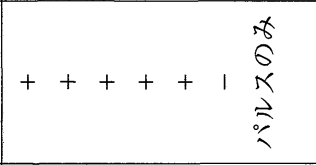 & 111 \\
\hline 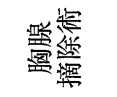 & $++1++11$ & 111 \\
\hline 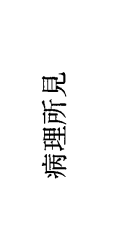 & 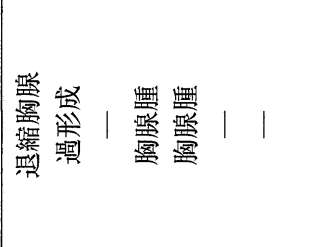 & 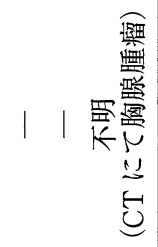 \\
\hline 逐 & 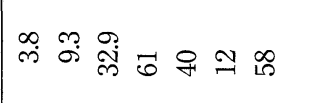 & $\stackrel{\sim}{\infty} \underset{\infty}{\infty}+$ \\
\hline $\begin{array}{l}\text { 煀 } \\
\text { 泽 }\end{array}$ & ลे ลิ $\rightarrow$ ลิ $\rightarrow+$ & $\neg-$ ลิ \\
\hline 蓄 & 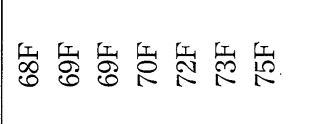 & 忘岸茝 \\
\hline
\end{tabular}

\section{成 績}

1991 年 4 月から 2003 年 12 月の間に $M G$ 入院例が 58 例あった５0歳代にピークがあり，女性，全身型が多 数を占めていた（図 1，2）.

(1)高齢群と非高齢群の検討： 65 歳以上の発症例は 11 例 $(19.0 \%)$ であった。高齢群の内訳は眼筋型 4 例 (36.4\%)，全身型 7 例 (63.6\%) であった。抗アセチルコ リンレセプター抗体結合型（以下抗 AchR 抗体と略す） は 11 例全例が陽性であり，抗体価は平均 $27.2 \mathrm{nmol} / l$ (標 準偏差 $25.7 \mathrm{nmol} / \mathrm{l}$ ）であった４例 $(36.4 \%)$ で胸腺病 変 (胸腺腫 2 例, 胸腺過形成 1 例, 組織不明の胸腺腫瘤 1 例）を認めた（表 2).

高齢群（65 歳以上）と非高齢群（20 歳から 64 歳）の 比較では (表 3 ), 男/女比は高齢群で $2 / 9$, 非高齢群で $13 /$ 24 であった。抗 AchR 抗体は高齢群では全例が陽性で 抗体価は $27.2 \mathrm{nmol} / l$, 非高齢群では 29 例が陽性 $(78.4 \%)$ で抗体価は $48.2 \mathrm{nmol} / l$ （異常高值例：3,000nmol $/ l$ を除 く)であった. 胸腺病変の合併は高齢群で 4 例 (36.4\%： 胸腺腫 2 , 過形成 1 , 組織不明の腫瘤 1 ), 非高齢群で 12 例 (32.4\%: 胸腺腫 7, 過形成 3, 組織不明の腫瘤 2) であっ た. 眼筋型と全身型の比率は高齢群では $4 / 7$ であり，非 高齢群では $11 / 26$ であった. 高齢群 11 例中 10 例が当院 で治療を行った。1例のみ当施設でステロイド治療や胸 腺摘除術などの治療を行えなかった症例があった．治療 法は（表 2)，6例でステロイド薬が使用された．5例は 内服（プレドニゾロン 1 日量換算で最大量 $40 \mathrm{mg}$ /日〜 60 $\mathrm{mg} /$ 日)，1例はステロイドパルスのみを行った．4例で 胸腺摘除術が施行されていた. 4 例は抗コリンエステ ラーゼ薬（以下抗 $\mathrm{ChE}$ 薬と略す）のみで治療されてい た. 4 例 $(40.0 \%)$ で再燃を認め, このうち 2 例でクリー ゼがみられた.クリーゼがみられた 2 例では，1例は胸 腺摘除後からステロイド薬の継続投与を開始した症例 で，1例はステロイドパルスのみで経過をみていた症例 であった。他に経過中に再燃を来たした 2 例では， 1 例 はステロイド減量中止後（治療開始 6 年後）に再燃を来 たし，1例はステロイド減量中に(プレドニゾロン $20 \mathrm{mg}$ 隔日投与の時点で） 1 年以内に再燃を来たした。経過観 察期間平均 2 年 1 力月（6 カ月から 10 年 5 力月）であっ た. 高齢群で再燃やクリーゼを来たした 4 例は病型が重 度の症例が多く, 眼筋型の 4 例は大半は抗 $\mathrm{ChE}$ 薬のみ で経過良好であった，ステロイドを使用しなかった症例 は 4 例あった. 理由として, 眼筋型で抗 $\mathrm{ChE}$ 薬のみで 症状が軽快 (3 例), 糖尿病 (2 例), 超高齢 (84 歳 $: 1$ 例), 陳旧性肺結核（3 例）があった（重複あり). ステ ロイド内服を行った 5 例では副作用として, 耐糖能異常 
表 3 高齢群（65 歳以上）と非高齢群（20 歳～ 64 歳), 若年群（19 歳以下） の比較

\begin{tabular}{|c|c|c|c|c|c|c|}
\hline \multirow{4}{*}{$\begin{array}{l}\text { 男性 } \\
\text { 女性 }\end{array}$} & \multicolumn{6}{|c|}{ 発症年齢 } \\
\hline & \multicolumn{2}{|c|}{$\begin{array}{c}65 \text { 歳以上 } \\
11 \text { 例 }\end{array}$} & \multicolumn{2}{|c|}{$\begin{array}{c}20 \text { 歳 } ６ 4 \text { 歳 } \\
37 \text { 例 }\end{array}$} & \multicolumn{2}{|c|}{$\begin{array}{c}19 \text { 歳以下 } \\
10 \text { 例 }\end{array}$} \\
\hline & 2 & $18 \%$ & 13 & $35 \%$ & 4 & $40 \%$ \\
\hline & 9 & $82 \%$ & 24 & $65 \%$ & 6 & $60 \%$ \\
\hline 眼筋型 & 4 & $36 \%$ & 11 & $30 \%$ & 6 & $60 \%$ \\
\hline 全身型 & 7 & $64 \%$ & 26 & $70 \%$ & 4 & $40 \%$ \\
\hline \multicolumn{7}{|l|}{ 胸腺病変の合併 } \\
\hline 胸腺腫 & 2 & $18 \%$ & 7 & $19 \%$ & 0 & $0 \%$ \\
\hline 過形成 & 1 & $9 \%$ & 3 & $8 \%$ & 1 & $10 \%$ \\
\hline 組織不明 & 1 & $9 \%$ & 2 & $5 \%$ & 0 & $0 \%$ \\
\hline \multicolumn{7}{|l|}{ 抗 AchR 抗体 } \\
\hline 陽性 & 11 & $100 \%$ & 29 & $78 \%$ & 8 & $80 \%$ \\
\hline 陰性 & 0 & $0 \%$ & 8 & $22 \%$ & 2 & $20 \%$ \\
\hline 平均値 $(\mathrm{nmol} / \mathrm{l})$ & 27.2 & & 48.2 & & 31.7 & \\
\hline
\end{tabular}

(2 例)，感染性骨䯣炎（1 例), 浸出性中耳炎 (1 例), 脊椎圧迫骨折（1 例）を認めた（重複あり）.

非高齢群の全身型の治療経過をまとめると, 非高齢群 の全身型は 26 例あり，このうちの 25 例が当施設で治療 をうけた， 22 例でステロイド薬が使用された，全例内 服治療を受けていた（プレドニゾロン 1 日量換算で最大 量 $30 \mathrm{mg} /$ 日 $100 \mathrm{mg}$ /日). 10 例で胸腺病変がみられ (38.5\%: 胸腺腫 7, 過形成 1, 組織不明の腫瘤 2), 21 例 で胸腺摘除術が行われた。 12 例 $(48 \%)$ で再燃がみら れ，1例がクリーゼを来たした。

(2)眼筋型の検討：眼筋型は 21 例 $(36.2 \%)$ であった (表 4). 眼筋型症例は男性 8 例, 女性 13 例であり, 発 症時年齢は 4 77 歳で高齢群は 4 例, 非高齢群は 11 例, 若年群は 6 例であった。抗 AchR 抗体は 12 例 (57.1\%) が陽性であり，異常高值 $(3,000 \mathrm{nmol} / \mathrm{l})$ を示した 1 例 を除くと平均 $22.2 \mathrm{nmol} / \mathrm{l}$ （標準偏差 $44.9 \mathrm{nmol} / \mathrm{l}$ ）であっ た. 治療法は，12 例 $(57.1 \%)$ でステロイド薬が使用さ れ，4例 $(19.0 \%)$ で胸腺摘除術が施行されていた。 ス テロイド薬の内服の最大量は 1 日量換算でプレドニゾロ ン $20 \sim 60 \mathrm{mg} /$ 日であった。抗 $\mathrm{ChE}$ 薬のみの治療例は 8 例 $(38.1 \%)$ であった. 抗 $\mathrm{ChE}$ 薬のみの治療例のうち 6 例が治療前の重症度 1 で，2例が重症度 2 であった。経 過観察期間平均 6 年 2 力月（3 カ月から 37 年）で 2 年 以上の症例は 10 例, 1 年以下の症例は 7 例であった. 全身型へ移行したと判断された症例は 1 例みられた。全 身型移行例は抗 $\mathrm{ChE}$ 薬のみで治療され, 発症から 37 年 後に全身型への進展がみられた。眼筋型 21 例中で症状 改善例は 16 例 $(76.2 \%)$, 著明改善例は 6 例 $(28.6 \%)$ で あった．著明改善例 6 例では， 4 例が治療前 ADL スコ
ア1の軽症例であったが，RSST で眼輪筋ないし鼻翼筋 で減衰がみられた症例が 3 例あった. 抗 AchR 抗体は 3 例が陰性であった. 2 例がステロイドを投与されていた. ステロイド薬が投与されていなかった 4 例では，重症度 1 の軽症例が抗 $\mathrm{ChE}$ 薬のみで治療されていた. 眼筋型 の高齢群の 4 例中 3 例は抗 $\mathrm{ChE}$ 薬のみで経過良好で あった．著明改善例以外の症状改善例では 9 例中 7 例で ステロイドが投与されていた. ステロイド薬が投与され ていなかった 2 例のうち, 1 例は胸腺摘除術と抗 $\mathrm{ChE}$ 薬の投与, 1 例は抗 $\mathrm{ChE}$ 薬のみで治療されていた。

治療後に重症度の改善がみられなかった症例が 5 例 あった。このうち 2 例が治療前の重症度 1 であり，3 例 が重症度 2 で難治例であった. 難治例 3 例では, 1 例が RSST で眼輪筋ないし鼻翼筋で減衰がみられ，1例が減 衰がみられず，1例は不明であった。抗 AchR 抗体は 2 例で陽性，1例で陰性であった。ステロイド薬開始まで の期間は， 1 例は 10 年を要していたが， 1 例は 2 年， 1 例は発症 5 力月後であった. ステロイド薬以外の治療と して，1例は胸腺摘除術を行い，1例は胸腺摘除術に加 えてタクロリムスの内服も行っていた．1例は治療経過 中に眼瞼挙上術を行っていた.

眼筋型で胸腺摘除術を施行した症例は 4 例あった。こ のうち 2 例は上記の難治例であり, 他の 2 例については, 1 例は抗 AchR 抗体が異常高值を示しており，1例は胸 部 CT で前縦隔に腫瘤を認めていた。前者の病理診断は 過形成, 後者は退縮胸腺であった。

\section{考察}

今回の検討では，過去 12 年間に当院神経内科に入院 


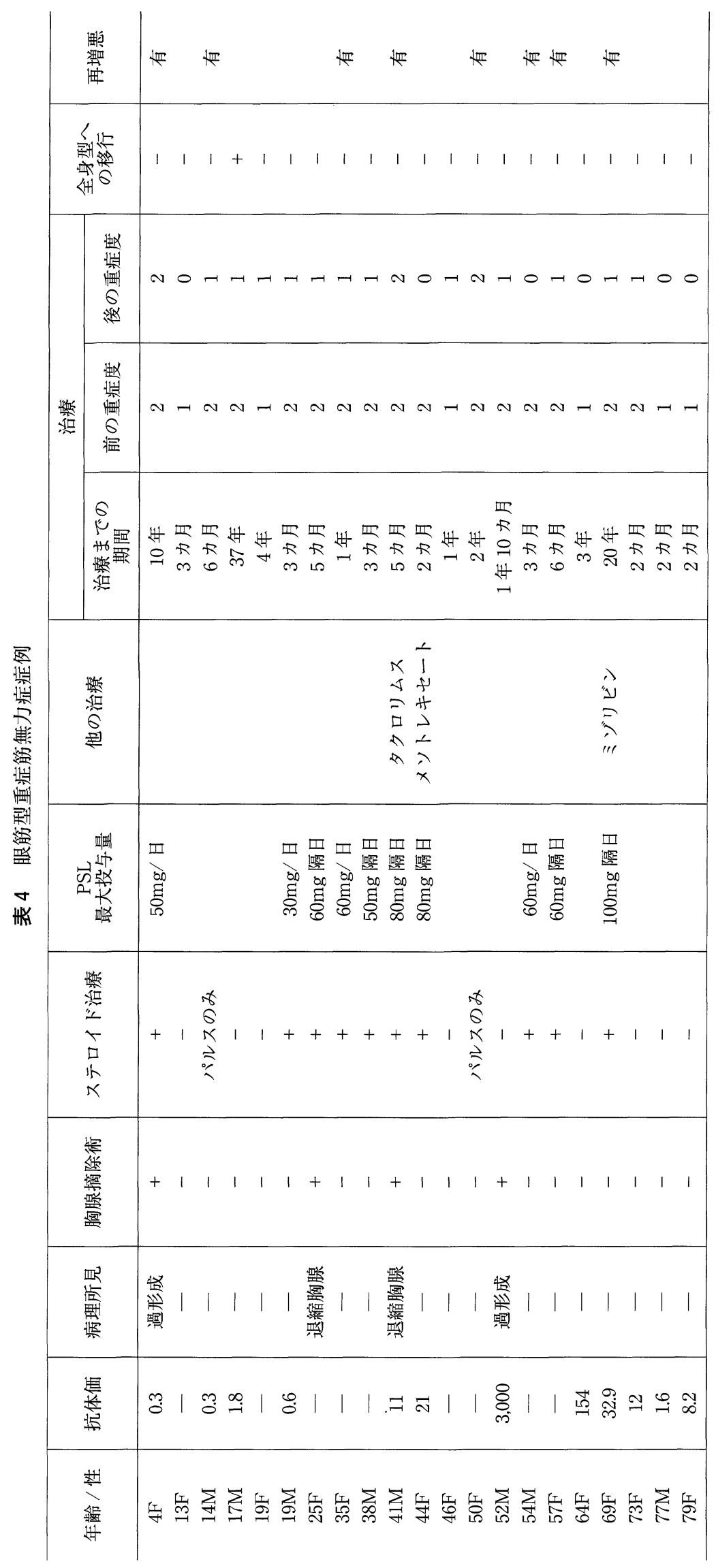


した MG 患者 58 例を対象とした. 50 歳代にピークがあ り, 女性の全身型が多数を占めていた. 本検討では治療 方針が未だ充分に確立されていない高齢発症および眼筋 型 $M G$ に焦点をおいて, 当院における治療と予後の検 討を行った。

$\mathrm{MG}$ 症例の男/女比は, 高齢発症では男性の比率が高 くなり，1.1〜1.4/1 程度になると報告されている3 ${ }^{3) 60}$. 一方, 日本老年医学会の過去の報告では, 女性の比率が 若年同様に高いとされていた (男/女 $=1 / 5$; 坂田ら, 2000 年, 男/女 $=1 / 6$; 鈴木ら, 2003 年 $)^{778)}$. 本検討でも 65 歳以上の高齢群の男女比は $2 / 9$ であり女性の比率が高 かった. 男女比は 60 歳以上では 4/10, 50 歳以上では 7/ 23 となり，いずれも女性の比率が高かった，本検討で は抗 AchR 抗体の陽性率は 100\%であったが，抗体価 は若年群, 非高齢群より低值であった。この点は過去の 報告と一致していた ${ }^{3)}$. 高齢群で再燃やクリーゼを来た した 4 例は, 病型が重度の症例が多い一方, 高齢群の眼 筋型は大半は抗 $\mathrm{ChE}$ 薬のみで経過良好であったことは 注目すべき点であった．また，高齢群の全身型は 6 例中 4 例 $(66.7 \%)$ で再燃がみられ，2例でクリーゼを来た した. 非高齢群の全身型は 25 例中 12 例 $(48.0 \%)$ で再 燃がみられ，1例がクリーゼを来たした．高龄群の人数 が少ないためそのまま比較は出来ないが, 高龄群の全身 型の再燃が多い傾向がうかがえる. 高齢群で再燃を来た した 4 例は, 胸腺摘出後からステロイド薬の継続投与を 開始した症例とステロイドパルスのみで経過をみていた 症例でクリーゼを来たし，ステロイド薬中止後とステロ イド薬減量中に再燃を来たした，ステロイド薬の導入， 減量が予後を考える上で重要と思われた。一方で，ステ ロイド薬継続投与例で耐糖能異常, 感染症, 脊椎圧迫骨 折を来たした症例がみられ，副作用，合併症も重要な問 題と考えられた。

$\mathrm{MG}$ 症例の $50 \%$ 以上が最初に眼瞼下垂や複視を訴え， 治療されなければ 2 年以内に筋力低下は全身に及び，2 年以上筋力低下が眼にとどまっていれば，全身型への移 行は 10 20\%である ${ }^{9) ~ 14)}$. 本検討で眼筋型から全身型 への移行例は 1 例のみしかみられなかった. 全身型移行 例は抗 ChE 薬のみで治療され, 発症から 37 年後に全身 型へ移行がみられており特筆すべき症例と思われた。経 過観察期間が 2 年以上の症例が 21 例中 10 例， 1 年以下 の症例が 7 例あり, 観察期間の短い症例が多かった点幾 分問題があったが，退院後に当院外来に通院していな かった症例については，転院先の病院に連絡し全身型へ の移行の有無を問い合わせた。本検討では抗 AchR 抗 体の陽性率は $57.1 \%$ であり, 従来の報告 $(50 \% \text { 程度 })^{10) ~ 13)}$ と同程度であった。従来, 難治例の危険因子として, 高
齢発症 ${ }^{12)}$, 治療前重症例, 抗 AchR 抗体陽性, RSST で の減衰現象，ステロイド薬開始の時期 ${ }^{133}$ が報告されてい る. 今回の検討では明らかな傾向はみられなかったが, 著明改善例は治療前軽症例が多く, 著明改善例以外の症 状改善例ではステロイド治療が多く行われていた。

当施設では従来全身型 MGについては平山らの報告 ${ }^{15)}$ に従って胸腺摘除とステロイド漸増の併用法を行い, 症 例によっては胸腺摘除術後にステロイド薬の併用を検討 した場合もあった。また，眼筋型では軽症例では抗 $\mathrm{ChE}$ 薬単独, 難治例ではステロイド薬や胸腺摘除の追加を 行っていた. しかし, 高齢群に限った明らかな方針は決 められておらず，基本的には病型に従って治療法を決定 し, 個々に検討を加えていた. MG の治療ガイドライン ${ }^{16)}$ によると, 胸腺腫を伴わない眼筋型 $M G$ では, 自然寛 解が存在することから抗 $\mathrm{ChE}$ 薬単独あるいは中等度の ステロイド薬の使用を試み，ステロイド薬を含む免疫抑 制薬に抵抗性あるいは全身型 $\mathrm{MG}$ への進展例は胸腺摘 除術を行うのが良い。高齢群では個々の患者について全 身状態や環境を配慮しながら, 胸腺摘除術を検討する必 要がある. 抗 $\mathrm{ChE}$ 薬, ステロイド薬などの薬物療法は 非高齢群と基本的には同様であるが，高齢群では合併症 が多く, 注意が必要であるとされている. 今回の検討で は高齢発症 $M G$ と眼筋型 $M G$ の治療方針は，基本的に はガイドラインに従った結果が示された．特筆すべき点 としては, 高齢群でステロイド薬の合併症とともにステ ロイド薬減量時の再燃に注意が必要であること, 高齢発 症の眼筋型 $\mathrm{MG}$ で抗 $\mathrm{ChE}$ 薬のみで経過良好な症例が多 くみられたこと, 眼筋型 $\mathrm{MG}$ 全体では著明改善例に治 療前軽症例が多くみられたこと, ステロイド薬を積極的 に使うことで全身型への移行を減少できる可能性がある ことが挙げられると思われる.

今回の検討の問題点として以下の 2 点が挙げられる. (1)外来通院症例からの MGのデータベースが不完全で あったため入院症例を取り上げた。このため, 眼筋型症 例の抽出にはバイアスがかかっている可能性がある. (2) 一施設 (大学病院) での調査であり, 症例に偏りを生じ ている可能性がある. 特に眼筋型で経過観察期間の短い 症例がみられた。今後, 多施設での比較検討を行い高齢 者 MGの治療方針をより明確にしたい.

\section{結 論}

今回行った MG58 例の検討では, 高齢群で非高齢群 と同様に女性の比率が高かった。高齢群ではステロイド の導入・減量はステロイドの副作用，他の合併症に関連 して慎重な対応が必要であり, 予後にも大きく関与して いると考えられた．また，眼筋型の検討では，全身型へ 
の移行例は 1 例認められ, 多数例で症状の改善を認めた. 多くの症例でステロイド治療が行われていたことが良好 な予後に寄与していた可能性が示唆された。

なお, 本論文の要旨は第 48 回日本老年医学会学術集 会（平成 15 年 6 月, 千葉）において発表した。

\section{謝辞}

今回の調査にあたりご協力いただいた諸先生方に深謝 いたします。

\section{文献}

1) Prowland $\mathrm{L}$ : Controversies about the treatment of myasthenia gravis. J Neurol Neurosurg Psychiatry 1980; $43: 644-659$.

2）佐藤 猛：重症筋無力症の QOL の多施設調査. 平成 7 年度厚生省特定疾患免疫性神経疾患調查研究班報告書 $1995 ; 19-21$.

3）森松光紀, 小松美鳥, 平井俊策, 岡本幸市, 江藤文夫： 50 歳以後に発病する重症筋無力症一 50 歳未満発病例と の比較. 日本老年学会雑誌 $1983 ; 20: 376-383$.

4) Aarli JA, Romi F, Skeie GO, Gilhus E: Myasthenia gravis in individuals over 40. Ann N Y Acad Sci 2003;998: 424-431.

5) Olanow CW, Lane RJM, Roses AD : Thymectomy in lateonset myasthenia gravis. Arch Neurol $1982 ; 39: 82-83$.

6) Donaldson DH, Ansher M, Horan S, Rutherford RB, Ringel SP : The relationship of age to outcome in myasthenia gravis. Neurology $1990 ; 40: 786-790$.
7）坂田尚弘, 小笠原淳一, 川井元晴, 根来 清, 森松光紀： 高齢発症重症筋無力症の臨床的検討. 日本老年学会雑誌 $2000 ; 37$ 臨時増刊号（学術集会抄録集）: 158.

8）鈴木 裕, 田村正人, 塩田宏嗣, 龟井 聡, 水谷智彦： 高龄発症重症筋無力症の検討. 日本老年学会雑誌 2003 ; 40 臨時増刊号（学術集会抄録集）: 125.

9) Grob D, Arsura EL, Brunner NG, Namba T: The course of myasthenia gravis and therapies affecting outcome. Ann N Y Acad Sci 1987; 505 : 472-499.

10) Evoli A, Tonali P, Bestorcian E, Manoco ML : Ocular myasthenia : diagnosis and therapeutic problems. Acta Neurol 1988; $77: 31-35$.

11) Schumm F, Wietholter H, Fatch-Moghadam A, Dichgans $\mathrm{J}$ : Thymectomy in myasthenia with pure ocular symptom. J Neurol Neurosurg Psychiatry $1985 ; 48: 322-337$.

12) Bever CT Jr, Aquino AV, Penn AS, Lovelace RE, Rowland LP: Prognosis of ocular myasthenia. Ann Neurol $1983 ; 14: 516-519$.

13) Sommer N, Sigg B, Melms A, Weller M, Schepelmann K, Herzau V, et al.: Ocular myasthenia gravis : response to long term immunosuppressive therapy. J Neurol Neurosurg Psychiatry 1997; 62: 156-162.

14) Oosterhuis HJGH: The natural course of myasthenia gravis. J Neurol Neurosurg Psychiatry 1989; 52 : 11211127.

15）平山恵三，伊藤直樹，小宮山純：重症筋無力症に扔ける ステロイド・胸腺摘除併用療法一特にステロイド術前・ 術後投与を中心に一. 神経進歩 $1986 ; 30: 160-171$.

16）重症筋無力症（Myasthenia Gravis）の治療ガイドライ ン・神経免疫疾患治療ガイドライン (http://www.fmu. ac.jp/home/neurol/guideline/PDF/MG.pdf)

\title{
Abstract
}

\section{Prognosis of patients with myasthenia gravis}

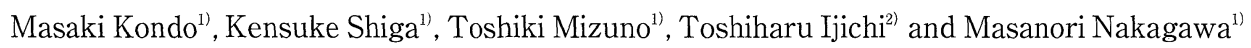

(Aim) To study the correlation between therapy and outcome of patients with late adult onset and ocular type myasthenia gravis $(\mathrm{MG})$.

(Methods) The $58 \mathrm{MG}$ patients admitted to our hospitals from 1991 to 2003 were classified into juvenile (younger than 20), early adult onset (20-64) and late adult onset (65 or older) groups, or also ocular and generalized types. We evaluated their therapeutic outcomes.

(Results) The late adult onset group consisted of 11 patients, classified as 4 ocular and 7 generalized types. There were more women than men in both the late and early adult onset groups. Anti-acetylcholine receptor (anti-AchR) antibodies were positive in all patients. Four patients had thymus lesions. Ten patients received treatment as follows : steroid therapy in 6, thymectomy in 4 and only choline-esterase ( $\mathrm{ChE}$ ) inhibitor therapy in 4 patients. However 4 patients worsened after treatment because of inadequate steroid therapy, 2 of whom experienced myasthenic crisis.

On the other hand 21 patients were ocular type, of whom anti-AchR antibodies were positive in 12 . They received treatments of the 21 , steroid therapy was given to 12 , thymectomy was performed in 4 and only ChE inhibitor therapy was given to 8 patients. One ocular type patient progressed to the generalized type. Six of 16 improved patients showed distinct recovery.

(Conclusion) In the late adult onset group careful assessment concerning timings of administration and reduction of steroid are required to avoid side effects and complications. One ocular type patient progressed to the generalized type and most patients had a good outcome, which might be related to steroid therapy.

Key words: Myasthenia gravis, Late onset, Ocular type,Therapy, Outcome

(Jpn J Geriat $2005 ; 42: 546-552$ )

1) Departments of Neurology and Geriatric Medicine, Kyoto Prefectural University of Medicine

2) Department of Neurology, Saiseikai Shiga Hospital 